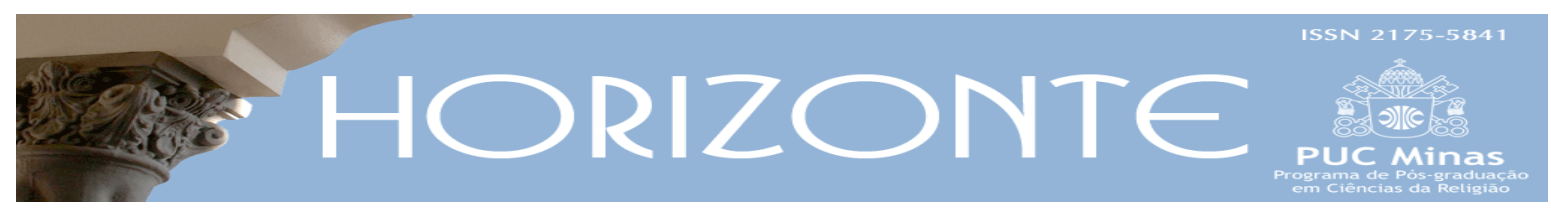

Temática Livre - Artigo Original

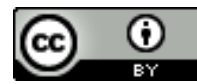

DOI - 10.5752/P.2175-5841.2016v14n43p952

\title{
Igreja e Estado, casamento, família e divórcio (Belém-Pará, 1916-1940)
}

\author{
Church and state, marriage, family and divorce \\ (Belém-Pará, 1916-1940)
}

Ipojucan Dias Campos*

\begin{abstract}
Resumo
Igreja Católica, Estado, casamento e divórcio são palavras-chave das reflexões que seguem. Mas o caráter central das interpretações é o de compreender, nas primeiras décadas novecentistas na cidade de Belém, as estratégias da Igreja Católica e as do Estado a respeito dos diálogos em torno do Código Civil Brasileiro de 1916. Mais especificamente, o estudo procurou interpretar o casamento, a família e o divórcio quando se buscava firmá-los à lei republicana. Todavia, enfatizese que tanto o Estado quanto a Igreja tinham as mesmas visões em relação à tríade, então, o casamento era indissolúvel, a família firmava as bases da sociedade e o divórcio estabelecia "apenas" a separação de corpos e bens; assim sendo, onde se localizavam as querelas entre ambas? Argumenta-se que as lutas correspondiam a quem competiria a jurisdição oficial sobre os institutos, pois Igreja e Estado pensavam serem instâncias de poder que desempenhavam incisiva força no seio da sociedade e por isso "donos" da moral e dos bons costumes.
\end{abstract}

Palavras-chave: Igreja Católica, Estado, Casamento, Divórcio.

\begin{abstract}
Catholic church, state, marriage and divorce are keywords of the reflections that follow. But the central character of the interpretations is to understand, in the first decades of nineteenth-century in Belém, the strategies of the Catholic Church and the State regarding the dialogues around the Civil Code of 1916. More specifically, the study sought to interpret marriage, family and divorce when they sought to steady them to the republican law. However, it is emphasized that both the State and the Church had the same views regarding the triad, then, marriage was indissoluble, the family he established the foundations of society and divorce established "only" separation of bodies and goods; if so, where they were located the bickering between the two? It is argued that the fights corresponded whom compete the official jurisdiction over the institutes, as church and state thought were instances of power that played incisive force in society and that "owners" of morals and good customs.
\end{abstract}

Keywords: Catholic Church, State, Marriage, Divorce.

Artigo recebido em 19 de janeiro de 2016 e aprovado em 04 de agosto de 2016

* Doutor em História Social da Pontifícia Universidade Católica de São Paulo (PUC / SP). Professor Adjunto IV da Universidade Federal do Pará (UFPA-IFCH) e professor do Programa de Pós-Graduação em Ciências da Religião da Universidade do Estado do Pará (UEPA). País de origem: Brasil. E-mail: ipojucancampos@gmail.com.

Horizonte, Belo Horizonte, v. 14, n. 43, p. 952-974, jul./set. 2016 - ISSN 2175-5841 


\section{Introdução}

Como o título anuncia, a cronologia deste artigo concentra-se entre 1916 e 1940. O seu local é a cidade de Belém do Pará. Igualmente se deve expor que nele há um princípio diretor que diz respeito às estratégias de leitura realizadas pela Igreja Católica e o Estado frente ao casamento, à família e ao divórcio no momento em que a República - outra vez - imiscuía-se nos interstícios dos seus sentidos e significados. Nesta seara, como lembra Campos (2004, p. 46) as lutas travadas em torno dos assuntos, nas décadas iniciais do século XX, ainda eram fortes ressonâncias oriundas do final oitocentista, pois em 1890 o Estado Republicano aprovou a secularização das bodas e do divórcio por meio do Decreto $\mathrm{n}^{0} 181$ de 24 de janeiro de 1890. Vinte e seis anos depois, em 1916, novamente através de uma lei aprofundavam-se os diálogos em torno da temática, porquanto, aprovava-se o primeiro Código Civil Brasileiro - que em muito versava sobre o conúbio, a família e a separação conjugal - demonstrando que a sua força não cessava de se mostrar à sociedade. Porém, núpcias, família e ruptura dos laços conjugais interessavam à Igreja, por isso atacava com todo vigor o afã de dominação que o Estado desejava realizar frente ao que compreendia ser apenas de sua competência, já que a interpretação dada por ela era a de que se tratava de pilastras elementares da coletividade. Assim, em matéria de ato solene e família, inexistia outra instituição apta a, no bojo da ordem, da moralidade, da durabilidade, realizá-los.

No campo das relações familiares, deve-se também esclarecer que, neste ensaio, usou-se o termo divórcio e não desquite porque o debate de então discorria a respeito da sua admissão na lei da época, ou seja, desejava-se implementar a ruptura a vínculo, o que significava separação conjugal com possibilidade de segundas núpcias em vida do outro cônjuge. Esta proposta não figuraria no Código Civil de 1916 e no Brasil apenas em 1977, após longas e aprofundadas querelas entre divorcistas e antidivorcistas, o desenlace podendo os apartados unirem-se em segundas núpcias foi aprovada nas leis brasileiras. Em conformidade, na legislação republicana das primeiras décadas do século $\mathrm{XX}$, permaneceu - em virtude da 
força da Igreja Católica - o princípio da indissolubilidade matrimonial e assim passou a ser utilizada a terminologia desquite que não punha fim ao casamento celebrado e sim "apenas" rompia convivência sob o mesmo teto e dividia os bens.

Sendo mais explícito a respeito da impossibilidade do segundo consórcio, a lei civil de 1916 dizia que o desquite poderia ser sustentado nas seguintes razões:

1. Adultério; 2. Tentativa de morte; 3. Sevicia ou injuria grave; 4. Abandono voluntario do lar conjugal, durante dois annos contínuos, 5 . Mutuo consentimento dos conjuges, se forem casados por mais de dois annos. (BRASIL, 1917).

Bem vistas as coisas, o argumento contido neste trabalho concentra-se na imagem de que havia, nas décadas iniciais novecentistas, intrigas constantes entre o Estado Republicano e a Igreja Católica frente à aliança matrimonial, à família e ao divórcio, mas sobre estes nenhuma das Instituições quis empreender mudanças profundas, aliás elas defendiam - no geral - os mesmos ideais a respeito do casamento, da família e da separação, por exemplo, as duas pensavam que a "boa" família era aquele constituída por um homem e uma mulher e que apenas a morte poderia separar os consortes. Então, qual era a tensão entre a Igreja e o Estado? A disputa concentrava-se frente à celebração que constituiria a família dita legal no Brasil, enfim, tratava-se de entreveros concernentes à lei e à mentalidade sobre qual Instituição dominaria o casamento vislumbrado como higiênico e moral. No entanto, as proposições ora apresentadas sustentam-se nos seguintes eixos: se por um lado a Igreja eficazmente teceu teias como a de propagandear que apenas o seu consórcio firmava e constituía a família monogâmica legal buscando com isso aproximar o sacramento do matrimônio ao cotidiano das pessoas (teoria próxima da prática), por outro o Estado utilizava, prudentemente, a seu favor, parte atinente ao casamento e à família do Código Civil de 1916, onde reafirmava que a secularização colocava o Estado como o único poder capaz de celebrar núpcias legítimas, bem como o resultado destas, a família. Diante da problemática, compreende-se que isso acontecia e acontece porque, em qualquer movimento, as

Horizonte, Belo Horizonte, v. 14, n. 43, p. 952-974, jul./set. 2016 - ISSN 2175-5841 
pessoas buscam produzir não apenas a solução da satisfação das suas necessidades, mas também elaboram outras necessidades redefinidas; neste ângulo, como demonstrado, na cidade de Belém, a Igreja e o Estado encontravam-se absolutamente envolvidos.

A considerar-se esta proposição inicial nunca se deve esquecer que as mesmas versavam pelos interstícios dos elos cotidianos, como também pela doutrina católica e pela legislação republicana. Assim, no interior desses aspectos, a partilha de poder não deve ser compreendida questão insípida; existiram forças e contra poderes atuando no bojo dos domínios diariamente percorridos pelos sujeitos sociais que ajudavam a formá-los, ou seja, dando contornos diversos ao que se constituía, com efeito, em campos complexos, amplos e dificultosos, neste sentido refere-se ao conúbio, à separação e à família. Mas, diga-se que estes são pousados em domínios sociais (na lei religiosa, na legislação civil e no cotidiano), todavia, como se expressavam neste lugar e ao mesmo tempo como se entrecruzavam estabelecendo ângulos pouco circunstanciais? Ao se interpretar tais campos localizaram-se interfaces constantes quando se pensaram os espaços nesta particularidade refere-se ao geográfico - juntamente com aqueles [os agentes sociais] que o construíram. A este respeito vislumbram-se, para estas reflexões, que os dois aspectos convergem, formando entre si paralelos constantes.

A folha "A Palavra", a brochura intitulada "Da Liga da Bôa Imprensa" e o Código Civil de 1916, foram os documentos que sustentaram estes diálogos. O periódico era de propriedade da Igreja Católica e teve tiragem bissemanal entre 1910 e 1941, a brochura foi material suplementar publicado, em 1915, pela "A Palavra”, logo da Igreja Católica. O periódico pode ser consultado na Hemeroteca Arthur Vianna, já o material intitulado "Da Liga da Bôa Imprensa" faz parte do acervo particular desse historiador. Para um contraponto lançou-se mão do Código Civil dos Estados Unidos do Brasil de 1916, onde a legislação republicana reafirmava a secularização (pois, no final do século XIX, com o Decreto 181 de 24 de janeiro de 1890 já havia definido que ele era o responsável pela celebração do 
conúbio e do desligamento a dois) do casamento e da separação conjugal como atos de sua responsabilidade. A legislação foi consultada na Biblioteca da Pontifícia Universidade Católica de São Paulo e também na da Faculdade de Direito do Largo de São Francisco da Universidade de São Paulo. Estas fontes mostraram-se capitais porque ofereceram - ao se colocar algumas questões - entendimentos diferenciados a respeito do que representavam o casamento, o divórcio e a família tanto por parte do Estado quando pelo lado da Igreja.

Porém, é necessário começar a interpretar os desejos das Instituições que ajudavam a elaborar a cotidianidade que se quer focalizar.

\section{Linguagens da ordem}

$\mathrm{Na}$ cidade de Belém, discutiam-se diversos tangenciamentos, lógicas e dimensões que versavam sobre o casamento, a família, o fim da convivência sob o mesmo teto, a idealização da esposa, da mãe perfeita, da casa, do lar, das relações conjugais, dos vínculos matrimoniais, da ordem, da moralidade. A respeito desses domínios, é inquestionável que o Estado e a Igreja permaneciam a enfrentar-se e concepções de ordem e desordem as Instâncias de poder [cada uma a seu modo], interpretavam como essenciais à sociedade. Essas imagens do campo do convívio social construíam reordenamentos de forma inumerável. Em conformidade, a exemplo da ordem e da desordem há um conjunto de variáveis que paradoxalmente, não apenas se repelem, mas se aproximam, a saber: os pares lícito e ilícito; desejável e detestável; tolerável e impossível de se tolerar são duplas por onde as ações sociais circulavam constantemente e consolidavam a ideia de que a dialética mostrava-se contida de forma indefinida nos entretecimentos cotidianos. Assim sendo, os domínios passavam inevitavelmente pelos espaços do compreendido como permitido e proibido na geografia em que os sujeitos atuavam, sendo imprescindível interpretar que áreas sociais jamais se encontravam cristalizadas ou sedimentadas, mas sim em constante movimento. Movimento que obedecia irremediavelmente aos interesses, às conveniências, às necessidades e às 
exigências ditas essenciais para se dar vida à dinâmica cotidiana que se mostrava presente no seio da cidade, do Código Civil, do ato solene, da família, do namoro, do divórcio, dos tensos elos conjugais que se firmavam em campos de disputa sejam as mantidas pela Igreja, sejam as de responsabilidade do Estado.

Frente o assunto, jamais se deve esquecer que a Igreja Católica belenense era força política expressiva no interior da coletividade; esta expressividade se fez exemplar nas discussões diante do Código Civil Brasileiro de 1916, quando barrou a aprovação do divórcio com possibilidades de segundo consórcio, deixando o casamento como ato indissolúvel, para toda a vida. Consequentemente, davam-se prevenções a temáticas como a do divórcio e as suas “possíveis” sequelas. Desse modo, concepções sociais e morais foram apresentadas pela Igreja, em 1915, em uma brochura intitulada "O divorcio".

Ei-las:

O divorcio compromete a educação dos filhos. Que importa que o divorcio comprometta a educação dos filhos, cujo espirito se conturba e cujos interesses não são escrupulosamente attendidos, quando os seus progenitores, esquecidos da sagrada missão que lhes é confiada, se deixam arrastar pelos desregramentos de conducta, sem procurar sequer disfarçal-os aos olhos das candidas criaturas que são fadadas a tomal-as por modelo, e em cujas consciencias esses actos produzem necessariamente um precipitado moral funestissimo? (DA LIGA, 1915, p. 05).

\section{Expôs o mesmo documento:}

O divorcio é a ruina da moralidade. A que monta, por sua vez a doutrina de Dias Ferreira, seja a perpetuidade a base necessaria da moralidade do lar domestico? que a destruição da indissolubilidade do vinculo seja a destruição da família, base da sociedade civil? que a indissolubilidade matrimonial esteja no traço de distincção entre o matrimonio e a prostituição legal reconhecida n `algumas nações? a que vem o egregio Lafayette definir o casamento como acto solenne pelo qual duas pessoas de sexo differente se unem para sempre, sob a promessa reciproca de fidelidade no amor e da mais estreita communhão de vida; communhão que é uma admiravel identificação de duas existencias, que confundindose uma na outra, correm os mesmos destinos, soffrem das dôres e compartem, com a egualdade, do quinhão de felicidade que a cada um cabe nas vicissitudes da vida? (DA LIGA, 1915, p. 05.). 
O divórcio seria a ruína da sociedade. A celebração do ato solene, a sua salvação. A Igreja compreendia ser o matrimônio rito indissolúvel e por isso quis exigir dos cônjuges conduta irrepreensível, de complementação quase sobrenatural das necessidades individuais e coletivas. Deve-se argumentar que a Igreja e o Estado incorporaram no conúbio carga de responsabilidade que acabou por criar zonas que sobrecarregaram a vida sob o mesmo teto o que, frequentemente, inviabilizou convivência longa entre as pessoas, isto é, na mediada em que a sobrecarga de exigências transformava-se insuportável a "única" saída que se apresentava era a da separação. Muszkat, (1992, p. 85-102) ao estudar as temáticas casamento e desligamento, percebeu que historicamente os pares se encontram demasiadamente envolvidos com as prescrições impostas pelas normas desejadas dominantes e se esquecem de que as núpcias se caracterizam em trocas constantes realizadas entre os próprios cônjuges.

Mas, o que queriam a Igreja Católica e o Estado em relação ao casamento e à família? O ponto crucial a se compreender é que nenhuma das instâncias preconizava mudanças substanciais nas estruturas da união e da família e por isso tinham as mesmas aspirações: desejavam o consórcio monogâmico e para a vida inteira, apenas que a morte separasse os casados, também dividiam a "certeza" que era apenas do casamento que a família higiênica era tributária e esta deveria ser vista como a base da sociedade. Então, onde se localizava a divergência? Tudo girava em torno de quem dominaria a celebração (casamento) dita legitimadora frente à sociedade, logo, a família, a moral e os bons costumes estavam presentes e em disputas.

As balizas onde deveriam ser sustentados o ato solene e as separações conjugais sempre suscitaram polêmicas. Os representantes do Clero novecentista desejosos de nesse assunto incursionar-se, influenciaram pontos que procuravam balizar as rupturas conjugais. As análises remetem a variadas dimensões de significados sociais (casamento, família, separação, moralidade, salubridade) e a Igreja Católica opunha-se a vários deles, todavia se expresse um: a da prerrogativa 
do divórcio jurídico. A este instituto permanecia contrária mesmo quando se tratava de ruptura no casamento civil, união não reconhecida por ela como legal. Mas deve-se aqui enfatizar que as duas Instâncias de poder discutiam a lisura [cada uma a seu modo] que se deveria dar às bodas, à separação e à família. Os grupos sociais em luta desejavam conquistar apoio no interior da sociedade e sem dúvida recusas e reticências foram inevitáveis, o que fazia com que precauções nunca se revelassem excessivas, porquanto a família muito perfeitamente se concentrava na esfera de normas de um jogo político desejado preciso onde o afã centrava-se em mostrá-la fechada e hierarquizada. Estratégias eventuais ou não de indivíduos ou de grupos jamais deveriam, pois vir à tona neste campo, então se observa que casamento, família e ruptura conjugal sempre suscitaram preocupações diversas; Aymard (1991, p. 455-499) mesmo refletindo para um tempo e espaço diferentes dos que são pensados para este artigo é aqui importante. O autor compreende que a família nunca foi temática secundária ao Estado, porque este a interpretava nas pilastras do essencial aos seus interesses em sociedade e sobre a Igreja diz que sempre a vislumbrou [a família] nos domínios de sua propriedade. Com efeito, aos interesses destas argumentações, o Estado e a Igreja discutiam os planos que envolviam campos compreendidos necessários à ordem social e, por isso, deveriam ter prudência e construir de modo preciso argumentos que não deixassem margens a ambiguidades.

Discutiam-se também quais seriam os espaços jurídicos a serem avançados e recuados no que dizia respeito aos elos de família e como estes deveriam ser enfrentados no cotidiano conjugal daqueles que optassem pelo fim da convivência sob o mesmo teto, por conseguinte segundo as análises de Dias (1992, p. 39-53), é necessário perceber os sujeitos sociais como agentes-condutores de si mesmos. Ao ligar a autora a estes argumentos, mundo social bastante complexo e amplo se mostra, ou seja, o casamento, os filhos, a moralidade pública e privada, enfim, aspectos da família apresentam-se com maior vigor. Assim, uma das problemáticas contidas era a de delimitar, de modo preciso, possíveis liberdades e isolamentos frente ao mundo conjugal. Por outros meios, este campo não poderia dar margem a 
manobras e nem parecer socialmente flexível a ponto de as pessoas o manipularem conforme conveniências e necessidades particulares. Desejava-se formar pontos bem dados socialmente, sem possibilidades de duplas interpretações e nesse campo os jogos de política não cessavam um minuto sequer. Buscavam-se a todo custo formar ensejos compreendidos, insignes, ou melhor, de que o consórcio e a família não tivessem pluralidade de direção: que os caminhos fossem comuns a todo grupo social, por exemplo, de que o casamento se mostrasse monogâmico e indissolúvel.

Mas a organização social do casamento e da família constituía-se de forma muito diferente e diversificada quando se pensam as molduras que se desejavam imprimir à totalidade familiar. O que se encontra no período em estudo, no entanto, são aspectos diversos de comportamentos familiares, os quais muitas vezes distanciavam-se dos modelos cristalizados pretendidos pela Igreja Católica e pelo Estado Republicano, então, compreende-se que o núcleo familiar era organizado conforme as conveniências que o momento exigia. É nesta dimensão cotidiana que se recorre a Scott (1990, p. 23-56), posto que a autora vislumbra que mulheres e homens nem sempre estão de acordo com as determinações e prescrições exigidas pela sociedade de que fazem parte. No caso específico de Belém, encontraram-se modelos que deveriam ser percebidos como campos que cimentavam a família, mas obviamente domínios que negavam a constituição familiar na instância de evento uno. Em conformidade com isso, as separações conjugais devem ser vislumbradas e relacionadas a partir das dinâmicas e representações que a vida conjugal diária apresentava. Assim é preciso apreender as formas de organização histórica do dia a dia daqueles que desejavam e optavam pelo fim da vida em comum.

Discursos e lutas sociais estavam presentes e funcionavam como formadoras de opinião no seio da sociedade belenense. Para se refletir estes espaços tomam-se emprestadas as compreensões acerca do direito elaboradas por Michel Foucault. A respeito, Foucault (2003) enceta que há no bojo das esferas dos discursos práticas sociais que podem constituir-se em domínios de saber, ou seja, a análise da 
narrativa deve ser tratada e percebida por meio de conjunto de fatos os quais se apresentam interligados através de regras políticas e sociais e que possuem o objetivo de mostrar de modo uniforme, aos sujeitos sociais, as maneiras pelas quais as relações deveriam ser organizadas. Nestes domínios, entende-se que os agentes sociais buscavam os seus próprios interesses o que se firma na lógica de que a norma não é capaz de circunscrever a todos: sempre haverá personagens sociais burlando o que é compreendido como correto. Se assim vislumbrado, deve-se comungar com a concepção de que o Estado e a Igreja não dispunham de qualquer possibilidade de lograr êxito em suas cristalizadas empreitadas diante de qualquer forma de união e de família.

Nesta conjuntura, conveniente é perceber as formas com as quais diversos domínios trouxeram tensões e foram apreendidos pelas pessoas que construíam as tramas na cidade de Belém. Desde os mais tenros debates, imprescindível era dar significado ao poder e para isso fazia-se necessário saber penetrar as ideias mesmo que fosse preciso lançar mão de estratégias antigas como a da indissolubilidade matrimonial, aliás, premissa que permaneceu fiel [na legislação da época, refere-se ao Código Civil de 1916] ao que determinava a Igreja Católica. Neste sentido, prática e teoria deveriam mostrar-se indissolúveis. Repitam-se, os jogos de força não poderiam ser reduzidos e circunscritos ao âmbito do direito, da Igreja ou do apetecido, porque existiam pessoas atuando cotidianamente, na "contramão" do que era desejado e compreendido salubre, dentre tais sujeitos sociais pode-se citar homens e mulheres que entravam com processos de desquite onde justificavam as mais variadas razões ao desligamento de corpos e bens (adultério, sevícia, injúria, imprevidência masculina e feminina, incompatibilidade de gênios); mas também é coerente colocar nesta lista as mulheres que impetravam autos de investigação de paternidade e alimentos contra homens um dia pensados como par perfeito à vida a dois. Com a tática política de procurar oferecer legitimidade aos discursos, a Igreja Católica nunca se encontrou afastada dos seguintes assuntos: namoro, casamento, família, divórcio e consequentemente do Código Civil. Sobre eles, 
afirmava não ser conveniente permitir generalizações e, ao divórcio dizia o seguinte:

O divorcio é uma infecção purulenta. Que importa que este mal necessario venha por contrapeso ao desafogo dos casamentos malsinados, a apagar o risco, já de si tão gasto, entre as uniões civis e a prostituição, que outra cousa não é o casamento temporário, o casamento por sessões, o casamento successivo, casamento provisorio, o casamento intermittente, que em gestação a lei do divórcio encampa e autorisa? Que importa que agindo como uma infecção purulenta o divorcio facilite, no dizer de Clovis Bevilacqua, o incremento das paixões animaes, enfraqueça os laços da familia, e essa fraqueza repercuta desastrosamente na organização social? (DA LIGA, 1915, p. 04-05).

A matéria revela, no entanto, oposições desejadas precisas sobre a ruptura conjugal e ao mesmo tempo defesa das esferas familiares. Lastros da tradição faziam-se convenientes, aliás, tais esferas encontram-se bastantes presentes na narrativa acima. Os sentidos dos elos sócio conjugais foram alvos de debates na imprensa belenense católica onde pairavam, nesses discursos, preocupações sobre a família. Com efeito, faziam-se jogos de poder para os quais apenas transformá-los em discurso não se mostrava suficiente para enfrentar ações sociais que subjaziam no cotidiano; por isso precisava-se montar circunstâncias práticas que viessem atuar nos interstícios do que se desejava alcançar: a vida em casal. As respostas deveriam ser rápidas e coerentes àqueles que queriam construir flexibilizações nas teias familiares, isto é, os jogos de política eram bem disputados, porém devem ser localizados para além das querelas pessoais dos sujeitos conquanto sua relevância encontrava-se no seio da importância do debate que concentrava e também nas perspectivas que seriam inauguradas com a nova lei; por isso, à Igreja a abertura de um domínio amplo e diverso mostrava-se indesejado, e por isso digno de acurado ataque, mas também senso de negociação. O que se configura é que o casamento e a família eram domínios inalienáveis tanto à Igreja quanto ao Estado e por esta razão existiam disputas intensas entre eles.

Todavia, diga-se que os entreveros não eram apenas em Belém, o Brasil vivenciava sérios conflitos políticos em torno desses assuntos. Para se dinamizar os debates recorre-se a Caulfield (2000), a historiadora mostrou que o Código Civil 
não conseguiu romper com determinações antigas diante do casamento, exemplar nesta linha de análise foi a sua fidelidade à Legislação Filipina. Silva (2003, p. 123146), afirmou à cidade de Goiás que lutas a respeito da união civil, entre a catolicidade e o Estado, eram avolumadas e envolviam interesses de família na mantença do poder local, isto é, as problemáticas que versavam sobre a secularização do casamento causaram muitas instabilidades no seio da cidade, pois, diz a autora que a cidade de Goiás mostrava-se lugar em que a catolicidade se fazia presente com força política, social e cultural, mas também o Estado era partícipe e desejava firmar as suas bases no lugar.

Assim sendo, se por um lado o poder secular buscava aproximar-se do conúbio, família e divórcio por meio da lei; por outro se observa que, nas narrativas construídas pela Igreja Católica, utilizavam-se caminhos variados para procurar estabelecer eficazes oposições aos campos que lhe causavam sobressaltos. À especificidade deste estudo, aqui, é necessário afirmar que a família em seu momento de constituição ou já formada era repleta de fantasmas que se infundiam nas experiências vivenciadas. Espectro perigoso a Igreja entendia ser o divórcio e contra ele empreendia ácida propaganda contrária; assim, categorizá-lo como "infecção purulenta" vislumbrou-se adjetivo primoroso. Esboçava-se de forma inteligível que, além da publicização de um projeto republicano que fazia incursões sobre as uniões conjugais, o Clero propalava os perigos que o Código Civil representava ao conjunto da sociedade. A Igreja, efetivamente, tinha com o que se preocupar.

Eis uma razão no ano de 1902:

O divorcio

A commissão especial da Camara ds Deputados terminou a 22 passado a votação dos arts. 218 a 411 do projeto do Codigo Civil, elaborado pelo Sr. Clovis Bevilaqua. A votação foi longa e relativa á parte que trata do direito de familia. Destacamos os votos da commissão sobre o divorcio ou separação de corpos estabelecido no projeto: por meio da emenda do $\mathrm{Sr}$. Sylvio Romero, foi incluída entre os motivos determinantes desse motivo de divorcio a tentativa de morte, e por emenda do Sr. Andrade 
Figueiras foi supprimida d'entre os motivos do divorcio da lei o mutuo consentimento. Assim os casos de separação de corpos ficam sendo os seguintes: adulterio, tentativa de morte, sevicia ou injuria grave e abandono voluntario do lar durante dois annos consecutivos. É possível, porém, que as requeresse a reconsideração do voto quanto á suppressão do mutuo consentimento. (O APOLOGISTA, 1902, p. 01).

Quatorze anos ainda faltavam para que o texto final do Código Civil Brasileiro obtivesse aprovação. O jurisconsulto Clovis Bevilaqua enfrentava dificuldades para aprovar determinados artigos e mesmo sessões inteiras que versavam sobre o casamento, a família e a separação conjugal; ao se ler o documento acima nota-se que as razões que possibilitavam juridicamente a ruptura entre esposos não estavam totalmente definidas, por exemplo, ainda não se sabia se o mútuo consentimento seria motivo à separação, o que significa a presença de extensos problemas, visto que havia, no Congresso, representantes dos dois lados em disputa. Como sobejamente especificado, querelas entre Estado e Igreja há muito ocorriam, tanto que se debatiam as expectativas que giravam em torno do Código em vias de promulgação, fato que fez retardar a sua conclusão. A este respeito recorre-se a uma especialista no assunto, Keila Grinberg, diz que no Congresso o projeto de lei elaborado por Clovis Bevilaqua demorou dezesseis anos somente para ser analisado, mas “(...) o processo completo levou 61 anos, se contados desde o primeiro contato do governo imperial para sistematização da legislação civil vigente, ou 94, levando em consideração a promessa feita em 1823 [...]”. (GRINBERG, 2001, p. 07-08).

Retorna-se, então, ao argumento central: para a Igreja Católica, conseguir sobreviver no seio deste longo diálogo fazia-se necessário estabelecer proximidades entre teoria e prática, isto é, se por um lado ela buscava elaborar incursões na vida dos cônjuges como a de afirmar que somente o seu ato solene viabilizaria longa vida entre os seus constituidores, de dizer que o consórcio civil não tinha a presença de Deus, de expressar que os que celebrassem somente o casamento cartorial estavam caminhando para o inferno; por outro, o Estado firmava posição na esfera de ser imprescindível aprofundar as balizas da secularização frente ao 
casamento, à família e ao divórcio, ou seja, claramente expunha que eles não mais diziam respeito à Igreja. Assim pensando, não era suficiente e tampouco conveniente que os discursos ficassem apenas no genérico, era imprescindível aproximá-los do cotidiano. Embora sua pesquisa seja distante cronológica e espacialmente dos deste artigo, recorre-se a Arnaud-duc (1991, p. 97-137). A autora descortina que os discursos concentrados no espaço do direito uniam-se aos morais. Conforme a historiadora, a razão desta aliança tinha por objetivo a tentativa de delimitar espaços que se buscava construir na linha do acessível e proibido aos diferentes agentes sociais. Nota-se que durante muito tempo, um dos objetivos foi o de tornar legítimas as desigualdades de tratamento. Agia-se para se procurar cumprir deveres entendidos reguladores dos movimentos e das ações sociais que passavam inevitavelmente por essas esferas. A Igreja Católica não se eximia destas dimensões debatidas cotidianamente. Tratava-se de sobressaltos os quais se lhe apresentavam incômodos, porquanto afirmava que as separações conjugais constituíam-se em chagas à sociedade, paixões animais que enfraqueciam os laços de família e essa fraqueza repercutia "desastrosamente na organização social”. Apreende-se que a Igreja forjava este discurso porque o Estado avançava nestas questões através da secularização e tais dinâmicas davam-se onde as tentativas de dominação voejassem, uma vez que as Instituições firmavam-se desejosas de demarcar território nos interstícios dos eixos: conúbio, família, separação, relações conjugais.

Nota-se que os diálogos que envolviam a secularização eram tensos. O documento a seguir é mais um dentre vários que pode ajudar nestes argumentos. É tão claro que a temática se apresentava essencial ao catolicismo, que expressar-se nestes tons jamais pode ser visto como circunstancial.

O catolicismo considerava:

O divorcio é a destruição de todo pudor. Admittindo-se o divorcio, a mulher assim como pode ter razão para separar do primeiro marido, e casar com um segundo, também pode ter razão para separar do segundo e 
casar com um terceiro, e assim por deante. Ora quem não vê que esta variedade causa a destruição de todo pudor? E ninguem diga que esta mudança tão repetida de maridos não tem realidade senão na minha imaginação. Pois já entre os romanos se dizia que as mulheres podiam contar os annos não pelos consules que governavam mas pelos dos maridos com quem estavam unidos. (A Palavra. 1921, p. 03).

Inexiste desejo de ser exaustivo com tantos exemplos demasiadamente evidentes acerca de como a Igreja se digladiava com o Estado. Ela possuía táticas tão inteligíveis e incisivas que nunca deixavam pousar dúvidas, chegando mesmo a não sair de única linha argumentativa, a da indissolubilidade matrimonial. $\mathrm{O}$ Estado jamais questionou este campo, porém era contrário ao domínio do Clero em matéria de matrimônio e separação. Em texto cronológica e espacialmente distante, todavia útil do ponto de vista metodológico, Philippe Ariès, argumenta que as estratégias da indissolubilidade matrimonial foram "o grande fato da história da sexualidade ocidental" observação reveladora, no entanto, enganam-se aqueles que a pensavam de forma simétrica ao cristianismo, ou melhor dito, como criação deste. O autor anota que tal noção encontrava-se entre os "pagãos" e com “marcantes influências do estoicismo". (ARIÈS, 1986, p. 163-182).

No campo dessas tensões, a ordem do discurso concentrava-se em procurar penetrar nas mais diversas instâncias sociais do cotidiano e sobre o divórcio, vejase o excerto a seguir:

O divorcio compromette a educação dos filhos. Que importa que o divorcio comprometta a educação dos filhos, cujo espirito se perturba e cujos interesses não são escrupulosamente attendidos, quando os seus progenitores, esquecidos da sagrada missão que lhes é confiada, se deixam arrastar pelos desregramentos de conducta, sem procurar sequer disfarçal-os aos olhos das candidas creaturas que são fadadas a tomal-os por modelo, e em cujas consciencias esses actos produzem necessariamente um precipitado moral funestissimo? (DA LIGA, 1915, p. 05).

Por meio destas exposições entra-se um pouco mais no que se pensava a respeito do casamento e da organização familiar na cidade. Observa-se que estes domínios eram desejados imperativos, uma vez que as lutas sociais, os campos de 
força e de interesse estavam formados. Imprescindia-se estabelecer sistemas de comunicação que apresentassem caráter cognoscível à sociedade; do mesmo modo, era indesejado que se constituíssem de forma dessimétrica entre os eixos praticados na cotidianidade e o que se buscava formar no espaço familiar. Lutavase contra quaisquer disjunções que envolvessem campos familiares. Nesta dimensão de análise, os desligamentos conjugais organizavam-se em domínios que possuíam caracteres incompreensíveis a determinados sujeitos e instituições da cidade de Belém, mas para aqueles que se separavam havia sentidos imediatos: o de escapar de uma convivência que não lhes era favorável. Fragmenta-se em larga medida a concepção de que as uniões não poderiam formar-se de modo contingencial, mas sim perene e que fossem capazes de sustentar a ordem e a moralidade. Porém, o que havia de tão perigoso na separação de corpos? Ao palmilhar os argumentos acima, apreende-se conjunto de razões que buscavam delimitar quais deveriam ser os espaços salubrizantes do casamento e da família. Nesta proporção, a dissolubilidade conjugal aproximava-se da instabilidade do lar. É forçoso, entretanto, acentuar que no momento em que se discutiam os artigos e os incisos do Código Civil Brasileiro, a Igreja Católica quisesse denotar legitimidade aos discursos que produzia. Torna-se oportuno perceber quais seriam os espaços a serem alcançados por meio das suas teses. Ela lançava mão de práticas pedagógicas que proporcionassem entrelaçamentos perfeitos à vida conjugal. Observa-se a este respeito que o recurso de se tentar educar as práticas sociais do casal e do futuro casal era elementar, sendo que esta educação ou a sua tentativa ocorreu por meio da doutrina católica, mas também através das seguintes posturas: a mulher como a responsável pelo lar, filhos e esposo e o homem na qualidade de mantenedor da casa. Esta estratégia de combate pretendia trazer para campo específico lutas encetadas no âmbito da sociabilidade privada da vida dos casados ou dos nubentes.

Entretanto, enfatize-se que tais problemas não eram particularidades da capital paraense. Na cidade de Campinas, Lopes (2002), ao interpretar sentidos e significados socioculturais do divórcio e desquite entre 1890 e 1934, passou em revista a legislação da época e percebeu que o local da sua pesquisa esteve imerso 
nos debates que giravam em torno da ruptura conjugal e familiar. Guardadas as devidas proporções, nada de diferente quando se pensa Belém. Sem dúvida, preocupações voejavam sobre a Igreja Católica, assim sendo as precauções deveriam ser tomadas e para isso o ideal de casamento católico era defendido de forma renhida por aqueles que não comungavam com a ideia da separação. Usavase como arma o futuro da prole. Com efeito, no saber dos discursos católicos contra o fim dos vínculos conjugais "as candidas creaturas" [os filhos] foram sobejamente utilizadas. Vislumbra-se, desta forma, que a Igreja Católica da capital paraense tinha dificuldades em manter o poder, uma vez que as transformações nos campos dos usos e costumes, culturais, sociais e políticos faziam-se e refaziam-se frequentemente. Ao estudar a urbe da época, Álvares (1990), a interpretou como espaço de tensão, porquanto mudanças se operavam no novecentos nos hábitos citadinos belenenses. Conforme as reflexões contidas em "Saias, laços e ligas" as mulheres conheceram mudanças que não devem ser vistas a maneira circunstancial e sim que ensejavam outros condicionamentos aos domínios sociais. Inquestionavelmente, conheciam maior trânsito nos espaços públicos. Mas estes jogos fora do recesso doméstico foram permeados de lutas. A Igreja Católica faziase presente e não via tais dinâmicas sem sobressaltos e mal-estar; para ela, o momento figurava-se intempestivo.

Argumentar contra reconfigurações que se estabeleciam, tomando por base os filhos e a moralidade constituía-se em estratégia expressiva. Para reforçar os discursos conservadores e moralistas católicos (a Igreja fazia, efetivamente, o seu papel), tomava-se sucessivamente como arma “a educação dos filhos”, isto é, arguia-se que com a separação conjugal a educação da prole ficava perturbada e “cujos interesses não são escrupulosamente attendidos, quando os seus progenitores, esquecidos da sagrada missão que lhes é confiada, se deixam arrastar pelos desregramentos de conducta [...]”. (DA LIGA, 1915, p. 05). O conúbio e o amor que envolvia os filhos eram lidos de forma homogênea; vislumbrava-se inadmissível [segundo a doutrina católica] que os progenitores esquecessem-se da tarefa assumida ao tempo do ato matrimonial: o de despender esforços necessários 
para que a unidade familiar não se rompesse. Pressões que envolviam a ordem, o social, a moralidade e que englobavam expectativas sobre as bodas e a maternidade são bem presentes nas teias dos discursos católicos. Desta maneira observam-se análises táticas para se deixar evidente o que se queria como costumes sociais e valores morais à cidade de Belém das primeiras décadas do século XX. Mesmo analisando outro tempo e espaço, Rago (1994, p. 28-44) aqui é conveniente. Segundo a autora, as transformações nos espaços culturais, sociais e políticos, os quais envolviam as cartografias conjugais, o ideário de consórcio, de amor e de paixão organizadas nas décadas iniciais do século XX eram algumas das razões que causavam instabilidade no bojo do dia a dia dos sujeitos sociais. Grupos de mulheres questionavam a partir do que a autora chamou de "sensibilidades modernas”, os campos do casamento, da família, do lar, da casa como precondição à felicidade a dois.

Retorna-se, deste modo, ao argumento anterior: as estratégias articuladas pela Igreja Católica ao tentar manter o que compreendia ser vida conjugal moralizante e que ficasse bem longe do Estado Republicano. Identificar estes jogos fronteiriços é essencial para sentir o que se pensava a respeito da idealização conjugal, pois se subjaziam campos de poder importantes, por exemplo, palavras e linguagens deveriam ser discernidas de modo inteligível, porque as personagens eram elaboradas no seio de aparatos de poder e representavam dinâmicas de interesse. Em importante livro, Foucault (2002) considerou que as dificuldades desses sujeitos sociais não se encerram na vizinhança das coisas, mas no lugar em que poderiam "avizinhar-se"; assim o intelectual concentrou suas análises na explicação de que a ordem das coisas é diferente da ordem das palavras e é por este motivo que os agentes devem ter atenção aos códigos ordenadores, porquanto é assim que se formam as ordens das coisas e, por conseguinte, o pensamento sobre as mesmas. A rigor, os discursos e as lutas sociais provocavam fricções, porque a Igreja Católica compreendia que as suas palavras não possuíam os mesmos significados para os diversos sujeitos sociais da cidade. Estes campos nevrálgicos eram alvos de ataques. Tratava-se, segundo a Igreja Católica, de procurar conter os 
deslocamentos característicos do mundo social; desta forma, uma das precauções tomadas firmava-se em aproximar-se do que se discutia no campo legal jurídico e do que se dialogava no mundo prático social. Os representantes da Igreja buscavam anular a possibilidade de a vida privada conjugal ser dotada de independência ou de permanecer sob os auspícios do Estado.

Entretanto, há reflexões históricas que se contrapõem à imagem da imobilidade católica. Ribeiro (1989, p. 129-153), interpretou algumas inegociabilidades da Igreja, mas também flexibilizações. Quanto ao laço solene, a pesquisadora afirma que o Clero sempre se manteve atrelado à lógica da fidelidade matrimonial e à união monogâmica indissolúvel e desta forma o pensamento católico colocava-se desfavorável a transformações que operassem mudanças profundas nas dimensões sociais. O conjunto de determinações contrárias que a Igreja mantinha em largo sentido não permitia negociação diante destes assuntos uma vez que, possuía por propósito central tecer discursos pedagógicos apreendidos universais pelos personagens que ela aspirava alcançar, ou melhor, essas alocuções concentravam-se na pureza da mulher, na mãe esmerada com o esposo e filhos, na rainha do lar; em relação aos homens deveriam ser excelentes provedores, bons maridos e pais. A Igreja descortinava que esta ordem era fundamental para que o matrimônio não terminasse no Tribunal de Justiça [poder secular] como Processo de Divórcio, Alimentos, Investigação de Paternidade ou Criminal. Assim, a Instituição não teria passado ao largo das modificações sociais operacionalizadas nas décadas iniciais do último século, mas procurou executar, da maneira que lhe fosse conveniente reelaborações sobre pressupostos seculares. 


\section{Conclusão}

Por tudo o que foi dito, deve-se intuir que inexiste história unilateral; não há um homem, um único homem desligado de outro ou de outros, ou seja, o homem é um complexo de outras pessoas. Isso a Igreja "pouco" compreendia ou se dava o direito de não compreender. Por outras palavras, ao tentar aproximar a doutrina religiosa do cotidiano ela "esquecia” a própria multiplicidade que emanava das pessoas, por exemplo, houve aqueles que passaram às margens das representações religiosas de matrimônio e mesmo da máxima do "até que a morte os separasse". Mas, deve-se aqui reafirmar que inquestionavelmente a Instituição executava o seu papel (propagandear a sua doutrina) apesar da distância entre o desejado e o possível. O Estado, por seu turno, buscava também manter sérias relações de poder com a Igreja, sempre com o propósito de influenciar a sociedade e em nada estava disposto a ceder quando o assunto se concentrava nas lógicas da secularização; ele compreendia que a maneira de se formar legalmente uma linhagem, bem como a de desligar os pais de obrigações recíprocas passava pelas suas mãos, pelo poder civil.

Desta maneira, casamento, família e divórcio apresentavam-se espetáculos fugidios, movediços, pouco dados a única representação, ou seja, é perda de tempo procurar compreendê-los como homogêneos. Então, como tudo na História, eles são entrelaçamentos inextrincáveis, porque combinam movimentos convergentes, divergentes, contraditórios. Por nunca caminharam por apenas um sentido à maneira do desejado da Igreja e do Estado, eles facilmente derivavam em confusão decisiva que implicava mais e mais em contratempos às duas Instâncias que neles se envolviam. Deve-se dizer aqui que a Igreja e o Estado localizavam-se, mas também eram localizados no seio das querelas que surgiam, porque inexiste sujeito que não elabore ressalvas às deliberações que o outro passa querer executar. 
Com efeito, fatos, desejos, anseios, afãs estão indubitavelmente articulados por elos de interesse do momento histórico assim, quando as pessoas percebiam que o casamento e, por conseguinte a família, não tinham mais sentido de ser, desfaziam-se as promessas [um dia realizadas] por meio de Processos de Divórcio. A Igreja "jamais compreendeu" que as lógicas de sucesso e fracasso do consórcio e da família ligavam-se aos movimentos individuais das pessoas, porém estes [os movimentos] formavam espaços múltiplos e entrecruzados.

Se o leitor vir estas interpretações razoáveis, há a necessidade de seguir pensando que seja a Igreja, seja o Estado, mesmo querendo, longe estavam de serem os senhores do destino da união, da família e da separação conjugal, ou melhor, das vidas das pessoas que os constituíam. Diga-se mais equitativamente, que estes jogos repontavam na falaciosa ilusão da possibilidade de um mundo a dois homogêneo, uma vez que esta pretensão sempre foi demasiadamente estreita e sem qualquer possibilidade de se consumar na prática cotidiana, mesmo quando a Igreja forçava uma severa ligação entre o teórico [a sua doutrina] e a prática cotidiana, quando o Estado prudentemente fazia valer a força da secularização no bojo da sociedade ou quando os dois se uniam para denegrir o casal que, por razões as mais diversas (adultério, imprevidência, injúrias, sevícias, incompatibilidade de gênios), optava pela separação de corpos e bens. Assim sendo, das relações de poder sérias consequências defluíam, pois se reafirme que toda problematização [desejada em equacionamento pela Igreja e pelo Estado] não cessava de complicálos. Os erros eram crassos. Os problemas, infinitos. A Igreja com a sua ânsia de dominação frente aos temas em pauta fez esquecer a necessidade da interpretação do movimentar da vida das pessoas e por isso "negligenciou" ou quis "negar" que cada sujeito é portador de ações insubstituíveis. Já o Estado, diga-se, não negava a importância do consórcio e da família e mesmo do modelo "imposto" pela Igreja (que em muito também era o seu), mas os queria sob o seu domínio. 


\section{REFERÊNCIAS}

ÁLVARES, M. L. M. Saias, laços e ligas: construindo imagens e lutas (um estudo sobre as formas da participação política e partidária das mulheres paraenses 1910/1937). 1990. Dissertação (Mestrado em Desenvolvimento) - Universidade Federal do Pará/Núcleo de Altos Estudos Amazônicos (UFPA/NAEA), Belém.

A PALAVRA. Belém, 23 de janeiro de 1921, p. 03.

ARIÈS, P. O casamento indissolúvel. In: ARIÈS, P; BÉJIN, A. (Orgs.). Sexualidades ocidentais: contribuições para a história e para a sociologia da sexualidade. São Paulo: Brasiliense, 1986, p. 163-182.

ARNAUD-DUC, N. As contradições do Direito. In: DUBY, G; PERROT, M. (Orgs.). História das mulheres no Ocidente. Vol. IV. Porto: Afrontamento, 1991, p. 97-137.

AYMARD, M. A comunidade, o Estado e a família. Trajetórias e tensões: amizade e convivialidade. In: ARIÈS, P; CHARTIER, R. (Orgs.). História da vida privada: da Renascença ao Século das Luzes. Vol. III. São Paulo: Companhia das Letras, 1991, p. 455499.

BRASIL. Código Civil dos Estados Unidos do Brasil. Vol. II. Rio de Janeiro: Imprensa Nacional, 1917

CAMPOS, I. D. Casamento, divórcio e meretrício em Belém no final do século XIX (189o/190o). 2004. 324f. Dissertação (Mestrado em História) - Pontifícia Universidade Católica de São Paulo PUC/SP, São Paulo.

CAULFIELD, S. Em defesa da honra: moralidade, modernidade e nação no Rio de Janeiro (1918/1940). São Paulo: Editora da UNICAMP, 2000.

DA LIGA DA BÔA IMPRENSA. O divorcio. Belém: Secção de obras d`A Palavra, 1915.

DIAS, M. O. L. da S. Teoria e método dos estudos feministas: perspectiva histórica e hermenêutica do cotidiano. In: COSTA, A. de O; BRUSCHINI, C. (Orgs.). Uma questão de gênero. Rio de Janeiro: Rosa dos Tempos, 1992, p. 39-53.

FOUCAULT, M. A verdade e as formas jurídicas. Rio de Janeiro: NAU, 2003.

FOUCAULT, M. As palavras e as coisas: uma arqueologia das ciências humanas. São Paulo: Martins Fontes, 2002.

GRINBERG, K. Código Civil e cidadania. Rio de Janeiro: Jorge Zahar Editor, 2001, p. 07-08. 
LOPES, C. F. Quod Deus conjuxit homo non separet: um estudo de gênero, família e trabalho através das ações de divórcio e desquite no Tribunal de Justiça de Campinas (1890/1934). 2002. 215f. Dissertação (Mestrado em História) - Instituto de Filosofia e Ciências Humanas (IFCH/UNICAMP), Campinas.

MUSZKAT, M. Descasamento: a falência de um Ideal. In: PORCHAT, I. (Org.). Amor, casamento, separação: a falência de um mito. São Paulo: Brasiliense, 1992, p. 85-102.

O APOLOGISTA Christão Brasileiro. Belém, o6 de janeiro de 1902.

RAGO, L. M. A sexualidade feminina entre o desejo e a norma: moral sexual e cultura literária feminina no Brasil, 1900/1932. Revista Brasileira de História/ANPUH. São Paulo, V. 14, n. 28, p. 28-44, 1994.

RIBEIRO, I. O amor dos cônjuges: uma análise do discurso católico. In: D `INCAO, M. Â. (Org.). Amor e família no Brasil. São Paulo: Contexto, 1989, p. 129-153.

SCOTT, J. El género: uma categoría útil para el análisis histórico. In: AMELANG, J; NASH, M. (Orgs.). Historia y género: las mujeres en la Europa Moderna y Contemporánea. Madri: Edicions Alfons el Magnànim, 1990, p. 23-56.

SILVA, M. da C. Catolicismo e casamento civil na cidade de Goiás: conflitos políticos e religiosos (1860 / 1920). Revista Brasileira de História/ANPUH. São Paulo, V. 23, n. 46, p. 123-146, 2003. 